\title{
Pengembangan LKPD Pembelajaran Sosiologi Berbasis Masalah dalam Meningkatkan Kemampuan Berpikir Kritis untuk Peserta Didik Kelas XI IPS SMA
}

\author{
Detari Elma Sagita ${ }^{1}$, Erianjoni Erianjoni ${ }^{2}$ \\ ${ }^{1,2}$ Universitas Negeri Padang \\ Email: detarielmasagita12@gmail.com, erianjonisosiologi@gmail.com
}

\begin{abstract}
Abstrak
Penelitian ini bertujuan untuk mengetahui kemampuan berpikir kritis pada Peserta Didik Kelas XI IPS SMA N 1 Kinali melalui pengembangan LKPD berbasis PBL. Penelitian ini dilatarbelakangi karena masih rendahnya kemampuan berpikir kritis peserta didik yang terlihat dari rendahnya kemampuan siswa dalam menyimpulan materi pelajaran. Maka perlu adanya metode untuk mestimulasi kemampuan peserta didik tersebut salah satunya menggunakan LKPD berbasis Problem Based Learning (PBL). Jeis penelitian ini Research and Development. Pengambilan data dilakukan melalui observasi dan pengisian angket (kuesoner) yang telah divalidasi kelayakan, praktikalis dan efektifitas LKPD oleh tim ahli. Hasil analisis menunjukkan bahwa pada validasi media dan materi yang diisi oleh 2 orang validator yang merupakan dosen sosiologi UNP, ada beberapa aspek yang terdapat dalam lembar validasi media dan materi yang mendapatkan nilai 0,72 dan masuk dalam kategori "tinggi". Angket uji praktikalitas di atas menunjukan bahwa hasil analisis penilaian praktikalitas oleh peserta didik memperoleh nilai rata-rata 0,80 dengan tingkat praktikalitas "tinggi". Hasil hitung validitas materi, media, dan praktikalitas membuktikan bahwa LKPD yang dihasilkan Valid dan Praktis. Hasil penelitian menyimpulkan bahwa (LKPD) berbasis PBL yang dihasilkan oleh peneliti berasa pada tingkat layak digunakan untuk pembelajaran sosiologi pokok pembahasan kelompok sosial pada peserta didik di kelas XI IPS 1 SMA N 1 Kinali. LKPD juga mampu membantu meningkatkan kemampuan berpikir kritis siswa.
\end{abstract}

Kata kunci: Berpikir Kritis, Lembar Kerja Peserta Didik, Pembelajaran Sosiologi, Problem Based Learning

\section{Abstract}

This study aims to determine critical thinking skills in Class XI IPS students of SMA N 1 Kinali through the development of PBL-based LKPD. The background of this research is that students' critical thinking skills are still low, which shows the low ability of students to conclude the subject matter. So it is necessary to have a method to stimulate the ability of these students, one of which is using LKPD-based Problem Based Learning (PBL). This type of research is Research and Development. Data collection is done through observation and filling out a questionnaire that has been validated for the feasibility, practicality and effectiveness of the LKPD by a team of experts. The results of the analysis show that in the validation of media and materials filled out by 2 validators who are sociology lecturers at UNP, there are several aspects contained in the media and material validation sheet that get a value of 0.72 and fall into the "high" category. The practicality test questionnaire above shows that the results of the practicality assessment analysis by students get an average value of 0.80 with a "high" practicality level. The results of calculating the validity of the material, media, and practicality prove that the LKPD produced is valid and practical. The results of the study concluded that the PBLbased LKPD produced by the researchers was at a suitable level for learning sociology, the subject of social group discussions for students in class XI IPS 1 SMA N 1 Kinali. LKPD is also able to help improve students' critical thinking skills.

Keywords: Critical Thinking, Problem Based Learning, Student Worksheets, Sociology Learning

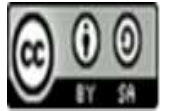




\section{Pendahuluan}

Pendidikan merupakan salah satu faktor penentu dalam menciptakan generasi bangsa yang siap menghadapi masa depan. Salah satu jenjang yang ditempuh oleh peserta didik dalam proses pendidikan adalah Sekolah Menengah Atas (SMA). Dalam proses belajar mengajar di SMA diperlukan pendekatan pengajaran yang tepat dibutuhkan guna melatih kemampuan berpikir tingkat tinggi siswa khususnya pada kemampuan menganalisis siswa. Sesuai dengan pendapat Johnson berfikir kritis ini merupakan kemampuan esensial yang harus dimiliki oleh peserta didik dalam memecahkan masalah. (Johnson, 2007)

Menurut Santrock pemikiran kritis merupakan pemikiran reflektif dan produktif, serta melibatkan evaluasi bukti. (Santrock, 2011). Jensen mempunyai pendapat bahwa berpikir kritis adalah suatu proses mental yang efektif dan handal, digunakan dalam mengejar pengetahuan yang relevan dan benar tentang dunia. (Jensen, 2011) Sedangkan Cece Wijaya juga mengungkapkan gagasannya mengenai kemampuan berpikir kritis, yaitu kegiatan menganalisis ide atau gagasan ke arah yang lebih spesifik, membedakannnya secara tajam, memilih, mengidentifikasi, mengkaji dan mengembangkannya ke arah yang lebih sempurna. (Wijaya, 2010).

Berfikir kritis mencakup kegiatan menganalisis dan menginterpretasi data dalam kegiatan inquiry ilmiah. The secretary's Commission and Achieving Neccessary Skill pada tahun 1990 menyatakan bahwa kompetensi berfikir kritis membuat keputusan, problem solving dan bernalar sebagai sesuatu yang penting dalam prestasi kerja. Menurut Sapriya, tujuan berpikir kritis adalah untuk menguji suatu pendapat atau ide, termasuk didalamnya melakukan pertimbangan atau pemikiran yang didasarkan pada pendapat yang diajukan. Pertimbangan-pertimbangan tersebut biasanya didukung oleh kriteria yang dapat dipertanggungjawabkan.(Sapriya, 2011).

Menurut Enis, kriteria atau elemen dasar yang harus dimiliki oleh pemikir kritis dalam memecahkan masalah adalah disingkat dengan Focus, Reason, Inference, Situation, Clarity, and Overview yang dapat disingkat dengan istilah FRISCO. Focus yang berkaitan dengan identifikasi fokus atau perhatian utama. Reason yang berkaitan dengan identifikasi dan menilai aksebtabilitas alasannya, inference yang berkaitan dengan menillai kualitas kesimpulan, dengan asumsi alasan untuk dapat diterima, situation yang berkaitan dengan situasi dengan saksama, clarity yang berkaitan dengan kejelasan, periksa untuk memastikan bahasanya jelas dan overview yang berkaitan dengan mengecek kembali atau langkah mundur dan lihat semuanya secara keseluruhan. (RH, 1996).

Salah satu cara untuk menumbuhkan cara berpikir kritis pada peserta didik adalah dengan cara menerapkan model pembelajaran berbasis masalah (PBL). Pembelajaran PBL mempunyai karakteristik pembelajaran aktif, mengangkat permasalahan kehidupan sehari-hari untuk merangsang pembelajaran dan pemikiran, serta membuat berlatih keputusan yang tepat (Sadlo, 2014). Menurut Akcay, PBL mempunyai karakteristik yaitu melibatkan peserta didik sebagai pemimpin dalam memecahkan masalah, mengorganisasi kurikulum yang mempunyai permasalahan holistik yang memungkinkan peserta didik untuk mengaitkan dan menghubungkan upaya pemecahan masalah, menciptakan lingkungan belajar dimana guru hanya sebagai fasilitator untuk peserta didik berpikir dan membimbing penyelidikan untuk mendapatkan pemahaman. PBL memiliki karakteristik yaitu diawali dengan pengajuan masalah-masalah kontekstual yang penting dan bermakna. (Akcay, 2009).

Ada beberapa faktor yang menyebabkan siswa memiliki kemampuan berpikir kritis yang rendah yaitu disebabkan oleh kondisi fisik, motivasi, kecemasan, dan perkembangan intelektual. Selain keempat faktor umum tersebut, terdapat beberapa faktor khusus yang menyebabkan rendahnya kemampuan berpikir kritis, diantaranya adalah proses pembelajaran yang berpusat pada guru, model pembelajaran yang cenderung ceramah, dan media pembelajaran yang monoton. 
PBL memiliki karakteristik yaitu diawali dengan pengajuan masalah masalah kontekstual yang penting dan bermakna, berfokus pada interdisipliner, penyelidikan otentik, pembelajaran kolaborasi dalam kelompok kecil, mempresentasikan penyelesaikan masalah (Bilgin, Şenocak, \& Sözbilir, 2009). Kumar menyatakan bahwa PBL mempunyai karakteristik dimulai dari masalah konteks kehidupan nyata, peserta didik melakukan penelitian, peserta didik mengaplikasikan teori untuk berlatih dalam proses pengembangan solusi, kolaborasi dalam kelompok kecil, guru sebagai tutor atau fasilitator, tanggung jawab peserta didik untuk belajar. (Kumar \& Refaei, 2013).

Hasil observasi awal di SMA N 1 Kinali pada mata pelajaran Sosiologi tepatnya pada materi Kelompok Sosial kelas XI 1 IPS 11, fakta yang banyak ditemukan adalah masih banyak peserta didik yang kurang aktif saat pembelajaran berlangsung dan hanya menerima pembelajaran tanpa dianalisa lebih kritis kembali. Rendahnya keterampilan berpikir kritis peserta didik ini juga dipicu oleh pembelajaran Sosiologi yang diajarkan masih dominan dengan menggunakan metode ceramah, yaitu guru menjelaskan dan peserta didik mencatat penjelasan guru. Dengan metode ceramah ini penyampaian pembelajaran akan lebih sistematis dan juga lebih ekonomis waktu. Namun, disisi lain metode ceramah menyebabkan pembelajaran didominasi oleh guru dan peserta didik belum menggunakan kemampuan berpikir kritisnya untuk menganalisa suatu permasalahan sosial dari berbagai sudut pandang. Dari beberapa jabaran definisi berpikir kritis di atas, peneliti membagi ciri berpikir kritis tersebut ke dalam 5 pokok indikator, diantaranya,1) dapat mendeteksi suatu permasalahan, 2) dapat memecahkan suatu permasalahan, 3) dapat mencari data dan menyesuaikan data dengan fakta yang ada di lapangan, 4) dapat mengolah dan menganalisis data dengan baik dan benar, 5) dapat menarik kesimpulan dan membuat sebuah laporan dengan benar.

Berdasarkan hasil wawancara dengan guru sosiologi SMA N 1 Kinali, respon siswa terhadap cara pembelajaran yang diterapkan oleh guru berbanding terbalik dengan ciri-ciri berpikir kritis yang dijelaskan oleh peneliti di atas, yaitu dalam mendeteksi suatu permasalahan, pada awal observaasi, peneliti melihat hanya 7 dari 31 siswa kelas XI IPS 1 SMA N 1 Kinali yang mampu mendeteksi suatu permasalahan saat guru menjelaskan materi kelompok sosial dengan metode ceramah, hal itu terlihat saat guru menjelaskan mengenai keluarga. Keluarga merupakan kelompok terkecil pertama dalam kehidupan, maka dari itu keluarga merupakan salah satu kelompok social sebagaimana terlihat pada tabel berikut:

Tabel 1. Indikasi Kemampuan Berpikir Kritis Siswa Kelas XI IPS 1 SMAN 1 Kinali

\begin{tabular}{clcc}
\hline No. & \multicolumn{1}{c}{ Indikator Berpikir Kritis } & $\begin{array}{c}\text { Siswa Yang } \\
\text { Mampu } \\
\text { Berpikir Kritis }\end{array}$ & Persentase \\
\hline 1. & Dapat mendeteksi suatu permasalahan & 7 & $22,5 \%$ \\
\hline 2. & Dapat memecahkan suatu permasalahan & 15 & $48,3 \%$ \\
\hline 3. & $\begin{array}{l}\text { Dapat mencari data dan menyesuaikan } \\
\text { data dengan fakta yang ada di lapangan }\end{array}$ & 20 & $64,5 \%$ \\
\hline 4. & $\begin{array}{l}\text { Dapat mengolah dan menganalisis data } \\
\text { dengan baik dan benar }\end{array}$ & 8 & $25,8 \%$ \\
\hline 5. & $\begin{array}{l}\text { Dapat menarik kesimpulan dan membuat } \\
\text { sebuah laporan }\end{array}$ & 4 & $13 \%$ \\
\hline
\end{tabular}

Sumber: Data Penelitian (2021)

Terlihat saat guru mulai menanyakan pada siswa mengenai penjelasan singkat tentang keluarga, 7 orang siswa yang menjawab pertanyaan guru mengenai keluarga merupakan kelompok sosial yang digolongkan pada kelompok sosial primer. Selanjutnya dilihat dari siswa dapat memecahkan suatu permasalahan. Pada ciri kedua ini juga peneliti melakukan observasi selanjutnya, peneliti melihat bahwa 15 dari 31 siswa kelas XI IPS 1 mampu memecahkan masalah, namun mereka membutuhkan waktu yang cukup lama dalam memecahkan suatu masalah, dan

Jurnal Sikola: Jurnal Kajian Pendidikan dan Pembelajaran Vol. 3, No. 2, Th. 2021 
16 siswa lainnya hanya bermain dan berbicara dengan teman sebangkunya. Hal ini peneliti lihat saat proses pembelajaran berlangsung pada materi masalah sosial. Guru memberikan satu gambar untuk 1 bangku, artinya siswa dapat mendiskusikan gambar tersebut dengan teman sebangkunya. Gambar yang diberikan adalah gambar kemiskinan. Setelah guru menjelaskan apa itu kemiskinan, guru menanyakan pada siswa solusi dalam mengatasi masalah sosial kemiskinan tersebut, namun tidak ada siswa yang menjawab pertanyaan dari guru. Setelah 3 menit berlalu, akhirnya ada 1 siswa yang menjawab pertanyaan, "yaitu dengan menyediakan lapangan kerja", lalu dilanjutkan oleh siswa ke 2, hingga berakhir pada siswa ke 15 .

Indikator berpikir kritis ketiga adalah dapat mencari data dan menyesuaikan data dengan fakta yang ada di lapangan. Diciri ketiga ini pada observasi selanjutnya peneliti menemukan bahwa 20 dari 31 siswa kelas XI IPS 1 SMA N 1 Kinali sudah dapat menyesuaikan data dengan fakta yang ada dilapangan, melalui contoh-contoh data yang diperlihatkan dari gambar oleh gurunya, dan mereka mampu melihat contoh lain yang ada di lapangan. Hal ini peneliti lihat saat observasi yang bersamaan dengan materi masalah sosial. Siswa mampu memberikan contohcontoh lain terkait materi masalah sosial, misalnya kenakalan remaja, pergaulan bebas, pengangguran, kriminalitas, dan contoh masalah sosial lainnya. Namun, yang memberikan contoh tersebut hanya 20 orang siswa saja.

Pada poin keempat terdapat ciri berpikir kritis yaitu dapat mengolah dan menganalisis data dengan baik dan benar. Dari ciri yang keempat ini, peneliti melanjutkan penelitian pada tahap lebih lanjut di kelas yang sama, yaitu XI IPS 1. Pada saat melakukan observasi peneliti menemukan bahwa hanya 8 dari 31 siswa yang mampu menganalisis data dengan baik, hal ini peneliti lihat dari guru memberikan tugas kelompok mengenai masalah sosial. Guru melihat dari hasil makalah kelompok siswa, setelah itu guru kembali memberikan pertanyaan terkait dengan isi makalah kelompok tersebut, pertanyaan yang diberikan guru hanya mampu dijawab oleh 8 orang siswa.

Ciri berpikir kritis terakhir adalah dapat menarik kesimpulan dan membuat sebuah laporan dengan benar. Poin kelima ini, peneliti menemukan fakta di lapangan bahwa hanya 5 dari 31 orang siswa di kelas XI IPS 1 SMA N 1 Kinali yang mampu membuat kesimpulan, dan 12 siswa lain hanya menunjuk temannya yang lain untuk memberikan kesimpulan pembelajaran saat diminta oleh gurunya. Hal ini peneliti lihat saat observasi di hari yang sama, diakhir pembelajaran guru ingin memberikan nilai tambahan bagi siswa yang mampu menarik kesimpulan terkait materi pembelajaran masalah sosial, 4 orang siswa mampu menarik kesimpulan pembelajaran walaupun tidak maksimal, namun untuk membuat laporan dengan baik dan benar, peneliti melihat dari makalah laporan masalah sosial yang dibuat oleh kelompok-kelompok siswa.

Beberapa peneliti telah melakukan penelitian tentang perlunya LKPD terintegrasi dalam pembelajaran yang perlu disesuaikan dengan model pembelajaran yang dipilih, diantaranya pada penelitian yang berjudul "dengan hasil penelitiannya adalah bahan ajar LKPD IPA berbasis pendekatan kontekstual dinyatakan layak berdasarkan hasil penilaian validasi LKPD IPA yang memperoleh skor dengan kategori sangat baik (A) dan perolehan nilai sig (2-tailed) sebesar 0,000 lebih kecil dari pada $1 / 2 \mathrm{a}=0,025$ yang menunjukkan bahwa dapat meningkatkan kemampuan berkpikir analisis peserta didik secara signifikan (Faturahman, 2017).

Penelitian yang berjudul "Pengembangan Bahan Ajar Lembar Kegiatan Peserta Didik (LKPD) Berbasis Inquiri Science Issues untuk Mengembangkan Critical Thinking Skills dan Curiosity Peserta Didik SMP" dengan hasil penelitian bahwa perkembangan critical thinking skills peserta didik setelah menggunakan LKPD berdasarkan lembar observasi memiliki kategori cukup dan hasil gain score ternormalisasi memperoleh kategori sedang. Perkembangan curiosity peserta didik setelah menggunakan LKPD melalui lembar observasi memperoleh kategori cukup dan melalui angket penilaian diri memperoleh kategori cukup. (Fatimah, 2017)

Abdul Majid menyatakan bahwa lembar kegiatan peserta didik (student work sheet) adalah lembaran-lembaran berisi tugas yang harus dikerjakan oleh peserta didik. Lembar kegiatan

Jurnal Sikola: Jurnal Kajian Pendidikan dan Pembelajaran Vol. 3, No. 2, Th. 2021 
biasanya berupa petunjuk, langkah-langkah untuk menyelesaikan suatu tugas. (Majid, 2013). Andi Pranowo menyatakan bahwa LKPD merupakan suatu bahan ajar berupa lembaran kertas yang berisi materi-materi, ringkasan, dan petunjuk pelaksanaan tugas pembelajaran yang harus dikerjakan oleh peserta didik yang mengacu pada kompetensi dasar yang harus dicapai. Perbedaan antara LKPD berfikir kritis dengan non kritis adalah komponen yang ada di dalam nya. LKPD berfikir kritis memiliki komponen lengkap C4 (Analysis), C5 (Syntesis), C6 (Evaluation), sedangkan LKPD non kritis hanya memiliki komponen C1 (Knowledge), C2 (Comprehension), dan C3 (Application) saja. (Prastowo, 2011). Untuk menunjang keterlaksanaan model pembelajaran berbasis masalah secara maksimal dan membantu meningkatkan kemampuan berpikir kritis siswa, maka peneliti mengembangkan LKPD (Lembar Kerja Peserta Didik) yang digunakan dalam aktivitas pembelajaran siswa.

Pengembangan LKPD pada penelitian ini berbeda dengan penelitian sebelumnya, dimana pada penelitian ini menggunakan LKPD berbasis PBL. LKPD ini dapat digunakan sebagai pembelajaran di sekolah dan di rumah. Tersedianya LKPD ini akan dapat menjawab masalah keterbatasan aktivitas pembelajaran terjadi pada siswa. Aktivitas pembelajaran di kelas akan dapat diatasi dengan penggunaan LKPD. Berdasarkan permasalahan yang ada serta karakteristik yang dimiliki oleh LKPD, maka pada artikel ini peneliti akan mendeskripsikan hasil penelitian pengembangan LKPD berbasis Problem Based Learning (PBL) untuk peserta didik kelas XI IPS SMAN yang telah diuji kelayakan dan kepraktisannya di SMA N 1 Kinali, Provinsi Sumatera Barat.

\section{Metode Penelitian}

Jenis penelitian yang digunakan adalah metode Research and Development atau disingkat dengan $R \& D$. Menurut Sugiyono penelitian $R \& D$ merupakan penelitian yang digunakan untuk menghasilkan produk tertentu dan menguji keefektivitasan produk tersebut. (A. Muri Yusuf, 2016). Penelitian ini bertujuan untuk menghasilkan LKPD berbasis Problem Based Learning (PBL) dan menguji tingkat validasi praktikalitas LKPD. Model pengembangan dalam penelitian ini adalah $4 \mathrm{D}$ (defiine, design, develop, disseminate). Tempat dan waktu dilaksanakannya penelitian ini yaitu FIS UNP dan SMA Negeri 1 Kinali pada semester genap tahun ajaran 2020/2021. Subjek dalam penelitian ini adalah 2 orang dosen Sosiologi FIS UNP sebagai validator dan guru serta 31 peserta didik kelas XI IPS 1 SMA N 1 Kinali sebagai subjek praktikalitas. Objek penelitian yaitu LKPD pembelajaran Sosiologi berbasis Problem Based Learning (PBL) untuk peserta didik kelas XI IPS SMA Negeri 1 Kinali.

Tahapan kegiatan penelitian yang akan dilakukan adalah: Tahap pertama define (pendefinisian), tahap pendefinisian merupakan tahap awal pengembangan LKPD. Langkahlangkah pokok tahap define, yaitu analisis awal, analisis peserta didik, analisis tugas, analisis konsep, analisis tujuan pembelajaran. Tahap kedua design (perancangan), merancang LKPD berbasis Problem Based Learning (PBL) yang relevan terhadap hasil pendefinisian. Tahap ketiga develope (pengembangan), adalah tahap untuk menghasilkan LKPD yang baik dan telah diperbaiki sesuai dengan saran dan masukan dari para ahli. Tahap develope memiliki empat tahap, yaitu (1) validasi produk, (2) revisi, (3) uji pratikalitas, (4) revisi produk. Dan tahap terakhir adalah disseminate (penyebaran), yang artinya produk LKPD sosiologi yang telah dikembangkan dapat disebarluaskan.

Teknik untuk mengumpulkan data, yaitu observasi, angket (kuesioner) dan wawancara. Adapun instrumen untuk mengumpulkan data, yaitu angket validasi ahli media, angket validasi ahli materi, dan angket praktikalitas peserta didik. Lembar angket validitas diberikan kepada validator untuk memberikan penilaian LKPD yang dikembangkan, sedangkan lembar angket praktikalitas diberikan kepada siswa untuk menyatakan penilaian praktis atau tidaknya LKPD yang telah digunakan dalam pembelajaran. Teknik analisis data dalam penelitian menggunakan

Jurnal Sikola: Jurnal Kajian Pendidikan dan Pembelajaran Vol. 3, No. 2, Th. 2021 
analisis statistik deskriptif untuk mendeskripsikan kevalidan dan kepraktisan LKPD yang dikembangkan. Data yang diperoleh dari hasil penyebaran angket dianalisis menggunakan Momen Kappa Cohen:

$$
\operatorname{Moment} \operatorname{Kappa}(k)=\frac{\rho_{o}-\rho_{e}}{1-\rho_{e}}
$$

Penggunaan rumus ini pada penelitian adalah berdasarkan instrument yang dinilai oleh valitador dengan keterangan sebagai berikut:

k: Moment Kappa / praktikalitas produk

$\rho_{0}$ : Proporsi terealisasi (Observed Agreement), yang dihitung dengan cara:

$$
\frac{\text { Iumlahnilai yang diberi validator }}{\text { Jumlahnilaimaksimal }}
$$

$\rho_{\mathrm{e}} \quad$ :Proporsi tidak terealisasi (Expected Agreement), yang dihitung dengan cara:

$$
\frac{\text { Jumlah nilai maksimal - jumlah yang diberi validator }}{\text { Jumlahnilai maksimal }}
$$

Momen Kappa (k) memiliki interpretasi nilai sebagai berikut:

Tabel 1. Kategori Penentu Hasil Penilaian Berdasarkan Moment Kappa (k)

\begin{tabular}{cc}
\hline Interval & Kategori \\
\hline $0,81-1,00$ & Sangat tinggi \\
\hline $0,61-0,80$ & Tinggi \\
\hline $0,41-0,60$ & Sedang \\
\hline $0,21-0,40$ & Rendah \\
\hline $0,01-0,20$ & Sangat rendah \\
\hline$<0,00$ & Tidak valid \\
\hline
\end{tabular}

Sumber: Sugiyono (Sugiyono, 2017)

\section{Hasil dan Pembahasan}

\section{Hasil Penelitian}

Pengembangan LKPD berbasis Problem Based Learning (PBL) materi kelompok sosial untuk peserta didik kelas XI IPS SMA N 1 Kinali dilakukan mengikuti prosedur penelitian pengembangan dengan menggunakan model $4 \mathrm{D}$. Adapun alur pengembangan menurut model ini mengikuti empat tahap yaitu, define, design, develop, disseminate. Berikut hasil pengembangan LKPD untuk setiap tahapnya.

\section{Tahap Define (Pendefinisian)}

Tahap awal dari penelitian adalah pendefinisian dengan menyusun rancangan awal. Berikut disajikan penjabaran hasil dari penelitian pada tahap pendefinisian

\section{Analisis Awal}

Analisis awal yang dilakukan yaitu Observasi di SMA Negeri 1 Kinali pada saat PLK Juli Desember 2020. Observasi bertujuan untuk memperoleh gambaran mengenai situasi dan kondisi sekolah yang berkaitan dengan penelitian pengembangan yang akan dilaksanakan. Observasi dilakukan dengan cara pengamatan dan wawancara kepada guru mata pelajaran Sosiologi pada saat proses pembelajaran dikelas XI IPS 1 SMA Negeri 1 Kinali. Hal-hal yang ditanyakan antara 
lain perangkat dan proses pembelajaran, alat, media pembelajaran dan perilaku peserta didik. Berdasarkan hasil dan wawancara dan observasi didapatkan informasi mengenai kurikulum yang digunakan di SMA Negeri 1 Kinali untuk kelas XI adalah Kurikulum 2013. Metode yang digunakan pada saat pembelajaran meliputi metode ceramah, tanya jawab, dan games. Perangkat yang disiapkan oleh guru sebelum proses pembelajaran diantaranya Rencana Pelaksanaan Pembelajaran (RPP). Hasil observasi awal didapatkan data bahwa masih rendahnya kemampuan berpikir kritis siswa ketika diterapkan metode ceramah dalam pembelajaran sehingga diperlukan LKPD untuk membantu meningkatkan kemampuan berpikir kritis siswa.

\section{Analisis Peserta Didik}

Analisis peserta didik bertujuan untuk mengetahui karakteristik peserta didik sebagai target pembelajaran yang berkaitan dengan kemampuan akademik, psikomotor, seta motivasi belajarnya. Karakteristik dari peserta didik dapat dilihat dari pengamatan yang dilakukan selama proses pembelajaran para peserta didik, mereka susah dalam mengkritisi materi yang diberikan oleh guru. Peserta didik cenderung memindahkan materi kedalam buku catatan tanpa dipahami terlebih dahulu. Metode yang digunakan guru cenderung membuat peserta didik merasa bosan karena pembelajaran hanya terfokus kepada guru sebagai pemberi materii (teaching center). Pada akhirnya peserta didik tidak mampu mengembangkan pemikiran yang mereka miliki. Hasil observasi awal didapatkan data bahwa masih rendahnya kemampuan siswa dalam mendefinisikan materi yang ditanyakan oleh guru.

\section{Analisis Tugas}

Analisis tugas bertujuan untuk menentukan isi dalam satuan pembelajaran sesuai yang ada pada kurikulum yang menjadi acuan yaitu kurikulum 2013. Analisis tugas pada materi kelompok sosial berupa analisis Kompetensi Dasar (KD), kemudian menentukan indikator pencapaian kompetensi. Adapun materi yang akan dikembangkan dalam LKPD pembelajaran sosiologi ini yaitu materi kelompok sosial. Tugas yang tepat dilakukan dalam meningkatkan kemampuan berpikir kritis siswa adalah berupa penugasan tentang rangkuman tentang materi yang akan dipelajari. Disini siswa diberi tugas tentang kelompok sosial yang ada di masyarakat dan penjelasannya mengapa terjadi kelompok sosisal tersebut.

\section{Analisis Konsep}

Pada tahap analisis konsep, peneliti mengidentifikasi konsep-konsep penting yang akan dibahas atau diajarkan pada materi kelompok sosial, kemudian disusun secara sistematis dalam bentuk peta konsep. Dalam pembuatannya memilih format yang menarik bagi peserta didik. Lembar Kerja Peserta Didik (LKPD) dibuat menarik dengan pemilihan cover LKPD, warna, bentuk, jenis tulisan yang digunakan serta ukuran penulisan nya. Sehingga menimbulkan ketertarikan bagi siswa sehingga diharapkan dapat memicu kemampuan berpikir kritis mereka.

\section{Analisis Tujuan Pembelajaran}

Tujuan pembelajaran yang dirumuskan oleh peneliti dan diharapkan dapat terpenuhi melalui materi kelompok sosial yaitu:

1. Melalui contoh kasus dan soal analisa yang terdapat dalam LKPD diharapkan peserta didik dapat menjelaskan definisi dari kelompok sosial. (Contoh kasus terdapat dalam LKPD).

2. Melalui contoh kasus dan soal analisa yang terdapat dalam LKPD diharapkan peserta didik dapat menemukan pengklasifikasian kelompok sosial (Contoh kasus terdapat dalam LKPD).

\section{Tahap Perancangan (Design)}

Pada tahap ini peneliti merancang draft perangkat pembelajaran dan isntrumen pengumpulan data yang kemudian divalidasi oleh validator ahli media, validator materi dan validator praktisi. Tahap perancangan terdiri dari: (1) Penyusunan Instrumen, yaitu dengan instrumen validasi ahli media dan materi yang diberikan kepada validator untuk dinilai; (2)

Jurnal Sikola: Jurnal Kajian Pendidikan dan Pembelajaran Vol. 3, No. 2, Th. 2021 
Pemilihan Media, yaitu LKPD berbasis Problem Based Learning (PBL); (3) Pemilihan Format, yaitu Lembar Kerja Peserta Didik (LKPD) dibuat menarik dengan pemilihan cover LKPD, warna, bentuk, jenis tulisan yang digunakan serta ukuran penulisannya; (4) Desain Awal, yang digunakan untuk merancang LKPD. Selanjutnya instrumen untuk mengukur pratikalitas diberikan kepada siswa kelas XI IPS SMA N 1 Kinali. Tampilan LKPD berbasis PBL dapat dilihat seperti pada gambar 1 berikut:

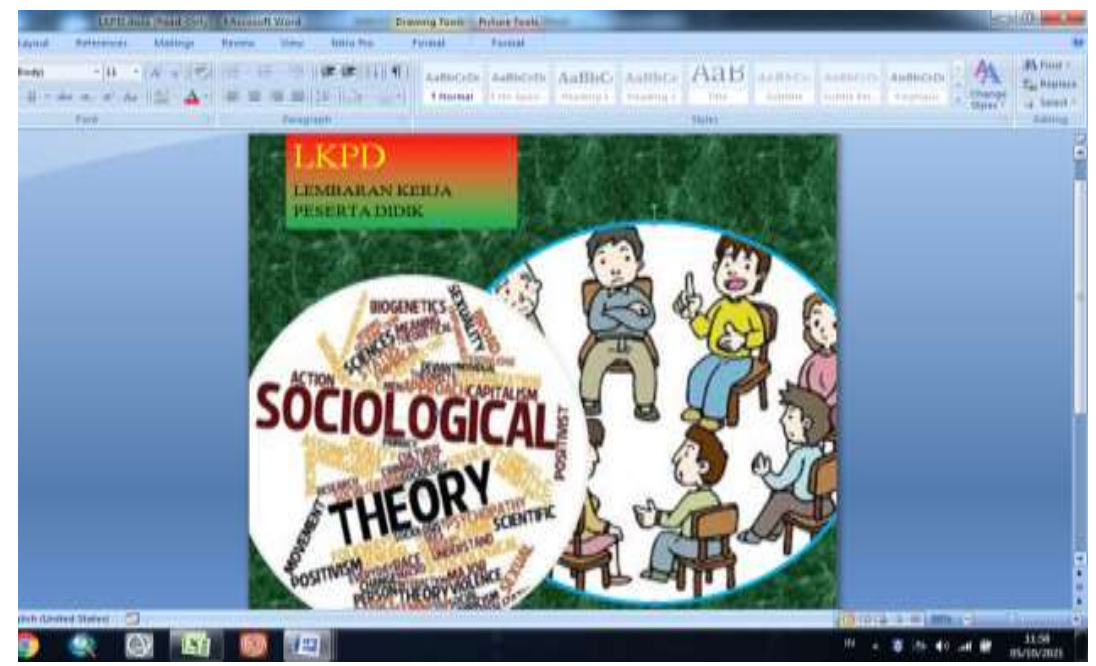

Gambar 1. LKPD berbasis Problem Based Learning (PBL)

Rancangan LKPD yang dibuat pada metode ini yang diasumsikan dapat mendorong kemampuan berpikir kritis siswa yang dibelajarkan melalui model PBL adalah:

1. Kegiatan yang mendukung materi dilengkapi dengan peta konsep dan soal yang mendukung pemahaman peta konsep. Soal yang disajikan dalam LKPD dikaitkan dengan kehidupan sehari - hari.

2. Bahasa yang disajikan menggunakan cita rasa LKPD namum tetap memperhatikan ejaan yang baik dengan tepat, kata atau istilah dengan tepat dan menggunakan kalimat yang baik dan benar.

3. Bahasa yang digunakan sederhana, lugas dan mudah dipahami peserta didik, baha sesuai dengan tingkat pertumbuhan peserta didik.

4. Materi yang disajikan mengaitkan peta konsep dengan konsep yang lainnya dalam menjelaskan suatu fenomena.

5. Tampilan gambar dengan menggunakan kualitas gambar baik dan tidak pecah, gambar pada halaman judul sesuai dengan isi materi yang sedang dibahas.

6. Penyajian materi memuat gambar - gambar penunjang materi dan gambar disajikan sesuai dengan kehidupan sehari - hari.

\section{Tahap Pengembangan (Develop)}

Tahap ini merupakan tahap yang bertujuan untuk menghasilkan LKPD yang baik dan sudah melewati proses perbaikan berdasarkan masukan dari para ahli. Tahap ini merupakan tahap merancang draft awal yang akan digunakan dalam pembelajaran materi kelompok materi kelompok sosial. Draft yang telah divalidasi dan telah melalui tahap revisi 1 diujicobakan ke sekolah. Uji coba dilakukan dengan melibatkan peserta didik kelas XI IPS 1 SMA N 1 Kinali. Kekurangan dari produk yang telah diujicobakan kemudian dilakukan revisi II. 


\section{Validasi Ahli Media dan Ahli Materi}

Validasi dilakukan oleh validator ahli dan validator praktisi. Adapun validator yang memberikan penilaian terdiri dari dua dosen sosiologi FIS UNP yaitu bapak JN dan ibu IS. Hasil validasi pada ahli ini telah mengindikasikan bahwa LKPD yang telah dibuat mempunyai validitas yang tinggi sehingga diasumsikan mampu mendorong kemampuan berpikir kritis siswa dalam pelaksanaannya, seperti terlihat pada tabel dibawah ini:

Tabel 2. Hasil Validasi Ahli Materi dan Media

\begin{tabular}{cccc}
\hline No & Nama Validator & $\boldsymbol{K}$ & Kategori Validitas \\
\hline 1. & Validator 1 & 0,83 & Sangat Tinggi \\
\hline 2. & Validator 2 & 0,61 & Tinggi \\
\hline & Rata-rata & $\mathbf{0 , 7 2}$ & Tinggi \\
\hline
\end{tabular}

Sumber: Data Primer (2021)

Hasil validasi oleh ahli media dan materi yaitu dilakukan oleh dua orang validator yang merupakan dosen sosiologi UNP didapatkan nilai kategori kepraktisan sebesar 0,72 dan masuk dalam kategori "tinggi". Hasil ini menunjukkan bahwa materi yang disajikan sesuai dengan indikator pencapaian kompetensi yang telah dirumuskan.

\section{Tahap Penyebarluasan (Disseminate)}

Tahap penyebarluasan dalam penelitian dilakukan dengan cara mengujicobakan LKPD pembelajaran sosiologi yang dikembangkan kepada Peserta Didik kelas XI IPS 1 SMA Negeri 1 Kinali. Penyebarluasan produk dapat dilakukan jika instrument telah divalidasi oleh para ahli. Pelaksanaan penyebarluasan produk disebarluaskan dengan memberikan produk berbasis daring (online) dalam bentuk google formulir kepada grup WhatsApp kelas XI IPS 1 SMA N 1 Kinali. Proses pembelajaran dilakukan secara daring, hal ini dikarenakan pandemi covid-19 sehingga pengembangan LKPD berbasis PBL tidak dapat dikembangkan secara tatap muka. Pertemuan secara daring dilakukan melalui grup WhatsApp sebanyak empat kali pertemuan. Pada pertemuan pertama peneliti memberikan soal pre-test kepada siswa dalam bentuk google formulir, sehingga skor siswa langsung diketahui, setelah itu peneliti menjelaskan materi yang akan di ajarkan yaitu materi KD 3.1 kelompok sosial.

Pada pertemuan pertama peneliti menjelaskkan tujuan dari pelajaran yang akan di ajarkan dan materi yang akan dibahas yaitu pengertian kelompok sosial dan jenis kelompok sosial dan pada akhir pembelajaran peneliti membagikan LKPD kepada siswa dalam bentuk pdf. Pertemuan kedua peneliti melanjutkan pembahasan materi jenis integrasi sosial. Pertemuan ketiga peneliti masuk pada materi faktor pendorong dan penghambat pembentukan kelompok sosial kemudian membagikan angket pratikalitas penilaian LKPD dalam bentuk google formulir, pada pertemuan keempat peneliti membagikan soal post-test kepada siswa dalam bentuk google formulir.

\section{Validasi Praktikalitas Siswa}

Pada tahap praktikalitas siswa ini dilakukan penerapan pembelajaran menggunakan LKPD berbasis PBL yang telah divalidasi tim ahli oleh terhadap siswa, dimana proses dilakukan secara daring. Pada tahap ini validasi praktikalitas LKPD dilakukan terhadap peserta didik kelas XI IPS 1 SMAN 1 Kinali yang berjumlah 31 orang. Pada tahap ini akan diketahui efektifitas peningkatan kemampuan berpikir kritis siswa setelah menggunakan LKPD Sosiologi yang dilakukan penilaian secara tes tertulis. Hasil pratikalitas LKPD dalam bentuk angket yang peneliti kembangkan dan yang telah di telaah oleh pakar adalah sebagai berikut: 
Tabel 3. Hasil Penilaian Praktikalitas LKPD oleh Guru

\begin{tabular}{clcc}
\hline No. & \multicolumn{1}{c}{ Butir Instrumen } & Kriteria & Kategori \\
\hline 1. & LKPD yang disajikan sangat menarik & 4,25 & Sangat Baik \\
\hline 2. & LKPD yang disajikan terstruktur & 4,5 & Sangat Baik \\
\hline 3. & $\begin{array}{l}\text { LKPD yang diasjikan memudahkan proses pembelajaran } \\
\text { siswa }\end{array}$ & 4,5 & Sangat Baik \\
\hline 4. & $\begin{array}{l}\text { LKPD yang disajikan membuat keefektifitasan belajar } \\
\text { terlaksana (dari segi aktivitas belajar dan waktu). }\end{array}$ & 5 & Sangat Baik \\
\hline 5. & $\begin{array}{l}\text { LKPD yang disajikan meningkatkan kemampuan berpikir } \\
\text { kritis siswa. }\end{array}$ & 5 & Sangat Baik \\
\hline & Rata-rata & 4,65 & Sangat Baik \\
\hline & Sumber: Data Primer (2021) &
\end{tabular}

Data di atas menunjukkan bahwa hasil analisis penilaian kisi-kisi secara rinci oleh peserta didik memperoleh nilai rata-rata 4,65 dengan kategori "sangat baik". Hal ini menunjukkan bahwa, LKPD yang dikembangkan disajikan sangat menarik, terstruktur, memudahkan proses pembelajaran siswa, membuat keefektifitasan belajar terlaksana baik dari segi aktivitas belajar dan waktu serta mampu dan meningkatkan kemampuan berpikir kritis siswa.

\section{Tabel 4. Hasil Praktikalitas oleh Siswa}

\begin{tabular}{clcc}
\hline No & Aspek yang dinilai & $\boldsymbol{k}$ & Kategori Kepraktisan \\
\hline 1 & Kemudahan Penggunaan & 0,83 & Sangat Tinggi \\
\hline 2 & Efisiensi Waktu Belajar & 0,78 & Tinggi \\
\hline 3 & Manfaat & 0,80 & Tinggi \\
\hline Rata-rata & 0,80 & Tinggi \\
\hline
\end{tabular}

Sumber: Data Primer (2021)

Tabel 4 diatas menunjukkan bahwa hasil analisis penilaian praktikalitas oleh peserta didik memperoleh nilai rata-rata 0,80 dengan tingkat praktikalitas "tinggi". Komponen kemudahan penggunaan memperoleh nilai sebesar 0,83 dan masuk dalam kategori "sangat tinggi". Hal ini menunjukkan bahwa, LKPD yang dikembangkan memiliki petunjuk penggunaan yang mudah dipahami. Penyajian materi yang jelas dan sederhana, serta keseluruhan isi dari LKPD mudah dipahami serta ukuran dan jenis huruf yang mudah dibaca.

Komponen efisiensi waktu belajar memperoleh nilai sebesar 0,78, dan masuk dalam kategori "tinggi". Ini menunjukkan bahwa LKPD pembelajaran sosiologi membantu peserta didik belajar sesuai dengan kemampuan belajarnya sendiri. Menurut Daryanto dalam (Zainul, 2020) Komponen manfaat memperoleh nilai sebesar 0,80 dan masuk dalam kategori "tinggi". Berdasarkan nilai yang diperoleh artinya LKPD membantu peserta didik untuk belajar mandiri, membantu peserta didik dalam memahami materi memahami materi karena disajikan gambar yang bertujuan mempermudah peserta didiak dalam memahami materi.

\section{Pembahasan}

\section{Tahap Pendefinisian (Define)}

Hasil observasi awal didapatkan data bahwa masih rendahnya kemampuan berpikir kritis siswa ketika diterapkan metode ceramah dalam pembelajaran sehingga diperlukan LKPD untuk membantu meningkatkan kemampuan berpikir kritis siswa. Terlihat bahwa metode yang digunakan guru cenderung membuat peserta didik merasa bosan karena pembelajaran hanya terfokus kepada guru sebagai pemberi materii (teaching center). Pada akhirnya peserta didik tidak mampu mengembangkan pemikiran yang mereka miliki. 
Penelitian sebelumnya tentang Pengembangan LKPD Sosiologi berberbasis PBL telah dilakukan oleh Sisra Elfina pada materi integrasi sosial menunjukkan bahwa terdapat peningkatan kemampuan siswa yang disebabkan pada fase orientasi, guru membahas tentang tujuan pelajaran dengan mendeskripsikan kebutuhan logistik sehingga dapat mengarahkan kemampuan siswa dalam berpikir kritis dalam mendefinisikan pokok masalah yang akan dibahas pada pembelajaran. (Elfina \& Sylvia, 2020). Sesuai dengan pendapat Arends bahwa terdapat lima fase atau langkah dalam model Problem Based Learning yang mencakup perilaku guru memberikan orientasi mengenai permasalahan pada peserta didik sehingga dapat memberikan motivasi pada peserta didik agar terlibat dalam kegiatan.

\section{Tahap Perancangan (Design)}

Pada tahap ini peneliti telah merancang draft perangkat pembelajaran dan instrumen yang telah divalidasi oleh validator ahli media, validator materi dan validator praktisi. Kemudian dilakukan pemilihan Media, yaitu LKPD berbasis Problem Based Learning. Pemilihan Format, yaitu Lembar Kerja Peserta Didik (LKPD) dibuat menarik dengan pemilihan cover LKPD, warna, bentuk, jenis tulisan yang digunakan serta ukuran penulisannya. Terlihat pada design ini LKPD berbasis PBL mampu meningkatkan kemampuan kritis siswa karena beberapa faktor yaitu: 1) Kegiatan yang mendukung materi dilengkapi dengan peta konsep dan soal yang mendukung pemahaman peta konsep. Soal yang disajikan dalam LKPD dikaitkan dengan kehidupan seharihari; 2) Bahasa yang disajikan menggunakan ejaan yang baik, kata atau istilah dengan tepat dan menggunakan kalimat yang baik dan benar; 3) Bahasa yang digunakan sederhana, lugas dan mudah dipahami peserta didik, baha sesuai dengan tingkat pertumbuhan peserta didik; 4) Materi yang disajikan mengaitkan peta konsep dengan konsep yang lainnya dalam menjelaskan suatu fenomena; 5) Tampilan gambar dengan menggunakan kualitas gambar baik dan tidak pecah, gambar pada halaman judul sesuai dengan isi materi yang sedang dibahas. 56 Penyajian materi memuat gambar-gambar penunjang materi dan gambar disajikan sesuai dengan kehidupan sehari-hari. Sesuai dengan pendapat Sapriya bahwa tujuan berpikir kritis adalah untuk menguji suatu pendapat atau ide, termasuk di dalamnya melakukan pertimbangan atau pemikiran yang didasarkan pada pendapat yang diajukan. Pertimbangan-pertimbangan tersebut biasanya didukung oleh kriteria yang dapat dipertanggungjawabkan. (Sapriya, 2009).

\section{Tahapan Pengembangan (Develop)}

Tahapan ini merupakan tahap yang bertujuan untuk menghasilkan LKPD yang yang LKPD yang disusun sudah divalidiasi oleh tim ahli. Uji coba juga telah dilakukan terhadap peserta didik kelas XI IPS 1 SMA N 1 Kinali serta melakuakn revisi terhadap masukan yang diberikan. Hasil validasi oleh ahli media dan materi didapatkan nilai kategori kepraktisan sebesar 0,72 dan masuk dengan indikator pencapaian kompetensi yang telah dirumuskan. Sesuai dengan pendapat Eggen dan Kauchak bahwa sintaks model pembelajaran PBL lebih terinci dan disertai dengan tujuan sintaks itu sendiri dilaksanakan. (Eggen, 2012). Secara umum jelas bahwa pada sintaks PBL diawali dengan memancing peserta didik untuk fokus pada pembelajaran, dengan kata lain pada langkah pertama ini diawali dengan membuka pembelajaran dan memberikan rangsangan kepada peserta didik agar siap dan fokus saat pembelajaran akan dimulai, lalu akan dilakukan proses pembelajaran melalui stratego-straregi yang sudah disiapkan oleh guru, serta diakhiri dengan diskusi dan menarik kesimpulan pada akhir pembelajaran terkait dengan materi yang dibahas dan kompetensi dasar serta indikator yang harus dicapai

\section{Tahap Penyebarluasan (Disseminate)}

Tahap penyebarluasan telah dilakukan dengan cara mengujicobakan LKPD pembelajaran sosiologi yang dikembangkan kepada Peserta Didik kelas XI IPS 1 SMA Negeri 1 Kinali. Hasil penilaian kisi - kisi secara rinoleh peserta didik memperoleh nilai rata-rata 4,65 dengan kategori "sangat baik". Hal ini menunjukkan bahwa, LKPD yang dikembangkan disajikan sangat 
menarik, terstruktur, memudahkan proses pembelajaran siswa, membuat keefektifitasan belajar terlaksana (dari segi aktivitas belajar dan waktu) dan meningkatkan kemampuan berpikir kritis siswa.

Hasil analisis penilaian praktikalitas oleh peserta didik memperoleh nilai rata-rata 0,80 dengan tingkat praktikalitas "tinggi". Komponen kemudahan penggunaan memperoleh nilai sebesar 0,83 dan masuk dalam kategori "sangat tinggi". Hal ini menunjukkan bahwa, LKPD yang dikembangkan memiliki petunjuk penggunaan yang mudah dipahami. Penyajian materi yang jelas dan sederhana, serta keseluruhan isi dari LKPD mudah dipahami serta ukuran dan jenis huruf yang mudah dibaca. Komponen efisiensi waktu belajar memperoleh nilai sebesar 0,78, dan masuk dalam kategori "tinggi". Ini menunjukkan bahwa LKPD pembelajaran sosiologi membantu peserta didik belajar sesuai dengan kemampuan belajarnya sendiri. Berdasarkan nilai yang diperoleh artinya LKPD membantu peserta didik untuk belajar mandiri, membantu peserta didik dalam memahami materi memahami materi karena disajikan gambar yang bertujuan mempermudah peserta didik dalam memahami materi serta mampu meningkatakan hasil belajar siswa.

\section{Kesimpulan}

Lembar Kerja Peserta Didik (LKPD) berbasis PBL yang dihasilkan oleh peneliti berada pada tingkat layak digunakan untuk pembelajaran sosiologi pokok pembahasan kelompok sosial pada peserta didik di kelas XI IPS 1 SMA N 1 Kinali. Hasil dari pengolahan data yangg dilakukan menunjukkan hasil bahwa validasi media dan materi yang diisi oleh 2 orang validator yang merupakan dosen sosiologi UNP, ada beberapa aspek yang terdapat dalam lembar validasi media dan materi yang mendapatkan nilai 0,72 dan masuk dalam kategori "tinggi", ini menunjukkan bahwa materi yang disajikan sesuai dengan indicator pencapaian kompentesi yang telah dirumuskan.

\section{Daftar Pustaka}

Akcay, B. (2009). Problem Based Learning in Science Educatio. Journal of Turkish Science Education, 6(1), 26-36.

Bilgin, I., Şenocak, E., \& Sözbilir, M. (2009). The Effects of Problem-Based Learning Instruction on University Students' Performance of Conceptual and Quantitative Problems in Gas Concepts. EURASIA Journal of Mathematics, Science and Technology Education, 5(2). https://doi.org/10.12973/ejmste/75267

Eggen, P. dan K. (2012). Strategi dan Model Pembelajaran Mengajarkan Konten dan Keterampilan Berpikir. Jakarta: Indeks.

Ennis, R.H. (1996). Critical Thinking. New Jersey: Printice-Hall Inc.

Elfina, S., \& Sylvia, I. (2020). Pengembangan Lembar Kerja Peserta Didik (LKPD) Berbasis Problem Based Learning (PBL) dalam Meningkatkan Kemampuan Berpikir Kritis Siswa Pada Mata Pelajaran Sosiologi di SMA Negeri 1 Payakumbuh. Jurnal Sikola: Jurnal Kajian Pendidikan dan Pembelajaran, 2(1), 27-34. https://doi.org/10.24036/sikola.v2i1.56

Fatimah, F. (2017). Pengembangan Bahan Ajar Lembar Kegiatan Peserta Didik (LKPD) Berbasis Inquiry Science Issues Untuk Mengembangkan Critical Thinking Skills dan Curiosity Peserta Didik SMP. Universitas Negeri Yogyakarta.

Faturahman, M. (2017). Pengembangan Bahan Ajar LKPD IPA Berbasis Pendekatan Konstektual Guna Meningkatkan Kemampuan Berpikir Analisis Peserta Didik. Universitas Negeri Yogyakarta.

Hasibuan, A. (2018). Efektivitas Kelas Ibu Hamil Terhadap Peningkatan Pengetahuan Ibu Hamil Tentang Faktor Risiko Dalam Kehamilan Di Wilayah Kerja Upt Puskesmas Semula Jadi Kota Tanjungbalai Tahun 2018. 
Jensen, E. (2011). Pemelajaran Berbasis Otak. Jakarta: Indeks.

Johnson, E. . (2007). Contextual Teaching and Learning: Menjadikan Kegiatan Belajar Mengajar Mengasyikkan dan Bermakna. [Make Teaching and Learning Activity be fascinating and meaningful]. Bandung: Mizan Learning Center.

Kumar, R., \& Refaei, B. (2013). Designing a Problem-Based Learning Intermediate Composition Course. College Teaching, 61(2), 67-73. https://doi.org/10.1080/87567555.2012.741079

Majid, A. (2013). Perencanaan Pembelajaran Mengembangkan Standar Kompetensi Guru. Bandung: Remaja Risdakarya.

Prastowo, A. (2011). Panduan Kreatif Membuat Bahan Ajar Inovatif. Yogayakarta: Diva Press.

Sadlo, G. (2014). Using Problem-Based Learning During Student Placements to Embed Theory in Practice. The Higher Education Academy, 2(1), 6-19.

Santrock, J. W. (2011). Educational psychology (5th ed). New York: McGraw-Hill.

Sapriya. (2009). Pendidikan IPS (Konsep dan Pembelajaran). Bandung: Remaja Rosdakarya.

Sapriya. (2011). Pendidikan IPS. Bandung: Remaja Rosdakarya.

Sugiyono. (2017). Metode Penelitian Kuantitatif, Kualitatif, dan R\&D. Jakarta: Alfabeta.

Wijaya, C. (2010). Pendidikan Remedial: Sarana Pengembangan Mutu Sumber Daya Manusia. Bandung: Remaja Rosdakarya.

Yusuf, A.M. (2016). Metode Penelitian Kuantitatif, Kualitatif \& Penelitian Gabungan. Jakarta: Prenada Media.

Zainul, A. A. D. and R. (2020). Pengembangan E-Modul Larutan Penyangga Berbasis Discovery Learning Untuk Kelas XI SMA / MA. 2(1). 